Journal of Emerging Markets Finance and Trade

\title{
The Transformation of Corporate Governance in Emerging Markets: Reform, Convergence and Diversity
}

Professor Thomas Clarke

Director

Centre for Corporate Governance

UTS Sydney

NSW 2007 Australia

Mob +61 409366791

t.clarke@uts.edu.au

\begin{abstract}
This article focuses upon the continuing tensions between the international movement for corporate governance reforms throughout the emerging economies, the insistent capital market pressures for convergence of emerging economies corporate governance towards international standards, the vibrant cultural and institutional tendencies in the emerging economies towards diversity in their corporate governance institutions and practices, and how these distinctive cultures and institutions of the emerging economies represent a vital differentiator which might delineate much of business development of these countries.

A brief survey of the business models and corporate governance of the major BRICS economies demonstrates the considerable differentiation that exists between them, but even more so, with the exception of South Africa, the BRIC economies stand in contrast to the Anglo-American model of developed legal and regulatory structures, and market oriented corporate governance. This suggests a vitality in the diversity of governance and institutions, which can continue to deliver high rates of business growth and economic development.
\end{abstract}




\section{Journal of Emerging Markets Finance and Trade}

\section{The Transformation of Corporate Governance in Emerging Markets: Reform, Convergence and Diversity}

\section{Introduction}

The emerging markets are engaged in a prolonged and chequered advance of their economies and institutions. In recent years the more rapid growth of the emerging economies compared to the developed economies increasingly was recognised. In a symbolic step the finance ministries and central banks of the respective countries took over from Goldman Sachs in publishing The BRICS Report (2012), focusing on the synergies and complementarities between the BRICS economies (Brazil, Russia, India, China and South Africa), the leading emerging market economies, which encompass over 40 per cent of the world's population, and account for 25 per cent of the total world GDP in terms of purchasing power parity, highlighting their role as growth drivers of the world economy (BRICS 2012:xiii). The IMF in the 2011 World Economic Outlook report forecast a three speed global economy, with growth strong in emerging and developing economies, recovering in the United States, and weaker in Europe. The emerging markets have become a major destination and source for foreign direct investment, receiving over half the total world FDI inflows and providing a third of the world's FDI outflows in recent years.

What exactly constitute the emerging markets is open to interpretation. The term 'emerging market economies' originated in the period of stock market internationalisation in the 1970s, highlighting the rapid economic progress of certain developing economies. The IMF, UNDP and World Bank each have differing definitions of developed, emerging and low income 
developing economies with different development thresholds, and the MSCI Emerging Market Index sets different criteria, as do other commercial indices (Nielsen 2011). However definitions are normally not simply based on level of income and economic growth but also institutional development: "The definition remains, however, a vague and evolving one. The most important features that differentiate emerging economies from the least developed ones are the advanced levels of institutional and regulatory infrastructure, as well as the liberalisation and internationalisation of capital flows and goods (Eurosif 2010).

The emerging economies have become increasingly attractive to the leading foreign multinationals searching for new markets, resources and skills. The evolution and sophistication of local markets has been enhanced by the activity of foreign multinationals, while home-grown multinational enterprises have evolved and are making their impact overseas entering developed markets (Santiso 2013; Lee 2013). Emerging markets have secured a stronger position in the international trade in goods and services, and in 2012 accounted for 39 per cent of goods flows and 37 per cent of financial flows, compared to 26 per cent of goods and 9 per cent of finance in 2002. Trade between emerging economies (South-South trade) has grown from 6 per cent of goods flows in 1990 to 24 per cent in 2012. According to the McKinsey in absolute terms, the increase has been from $\$ 198$ billion to $\$ 4.4$ trillion. This is reflected in the increasing presence of emerging markets in labour intensive manufactured goods including automobiles, computers and books, however the emerging markets are beginning to advance from production capability to innovation capability (Amman and Cantwell 2012). While the developed economies continue to dominate the flows of knowledge-intensive industries, the emerging economies are developing their foothold in this sector with China having the second largest knowledge intensive flows following the United States (McKinsey Global Institute 2014). 
As Kearney (2012) maintains the emerging markets are becoming an economic and social force of growing interest and significance:

"Emerging markets comprise the majority of the world's people and land, and they continue to grow faster than the developed world. They are increasingly recognised as a diverse set of business, cultural, economic, financial, institutional, legal, political and social environments within which to test, reassess and renew received wisdoms about how the business world works, to gain deeper insights into prevailing theories and their supporting evidence, and to make new discoveries that will enhance human welfare in all environments including the world's poorest countries, the developing world, the transition countries and the developed world" (Kearney 2012:160).

However the continuing vulnerability of the emerging market economies to the capital markets of the advanced economies was revealed in 2013, when the Federal Reserve announced the tapering of its post-crisis long term assets purchases, and with interest rates apparently set to rise, there was a resulting flight of capital back to the US (Davies 2014). Further the prospects of a hard landing for the Chinese economy became real as efforts by the Chinese authorities to attempt to switch away from an investment and export-driven growth model to one more focused on domestic consumer spending. Finally the end of the inflated global commodity-cycle posed a threat to all commodity producers, particularly in the emerging markets. This has refocused attention not only on any economic weaknesses in the emerging markets, but on the political and policy instability in emerging markets, and continuing weaknesses in institutional development. This was a sharp reminder of how in the recent past the seemingly inexorable advance of emerging economies has been thrown into 
crises as in Mexico 1994-95; East Asia 1997-1998; Russia 1998; Brazil 2000 and Argentina 2002.

Corporate governance is widely identified as critical to the institutional development of the emerging economies, and as an essential basis for stable and sustained economic growth. This article focuses upon the continuing tensions between the international movement for corporate governance reforms throughout the emerging economies, the insistent capital market pressures for convergence of emerging economies corporate governance towards international standards, the vibrant cultural and institutional tendencies in the emerging economies towards diversity in their corporate governance institutions and practices, and how these distinctive cultures and institutions of the emerging economies represent a vital differentiator which might delineate much of business development of these countries.

This theoretical approach is a contribution to the varieties of capitalism literature comparing different models of capitalism from alternative analytical frameworks highlighting the nature and extent of diverse forms of capitalism, their relative strengths and weaknesses, and the prospects for institutional diversity when confronted with growing pressures for international economic integration (Deeg and Jackson 2006). The varieties of capitalism thesis elaborated by Hall and Soskice (2001) adopts a firm centred approach focusing on the incentives for coordination; a wider typology of governance mechanisms in terms of social systems of production is offered by Hollingsworth and Boyer (1997); and a national business systems approach of Whitley (1999) examines the internal capacities of business firms. In summary this approach theorises that:

i. firstly national economies are characterised by distinct institutional configurations that generate system logics of economic action; 
ii. secondly there is comparative institutional advantage in which different institutional arrangements have distinctive strengths and weaknesses for different kinds of economic activity; and

iii. thirdly there is institutional path dependence (Jackson and Deeg 2006:3)

In pursuing a dynamic interpretation of institutional impact and the linkages between institutions and the wider political economy, this article examines the development of corporate governance in emerging markets, and the relationships between governance and regulation and economic growth are considered. The BRICS economies, institutions and governance are used as an illustration to demonstrate the differences between the BRICS and the dominant Anglo-American model of legal and regulatory structures. Finally how the pressures from capital markets for convergence are confronted by the resilience of continuing cultural and institutional differences is explored, concluding with an argument for cultural and institutional diversity of different governance models as the basis for dynamic differentiation in industries and markets.

\section{The Development of Corporate Governance in Emerging Markets}

There are many interpretations of what corporate governance encompasses. A simple yet broad definition was offered by the UK Committee on the Financial Aspects of Corporate Governance (Cadbury Committee 1992): “Corporate governance is the system by which companies are directed and controlled." But corporate governance has wider implications and is critical to economic and social well-being, firstly in providing the incentives and performance measures to achieve business success, and secondly in providing the accountability and transparency to ensure the equitable distribution of the resulting wealth. The significance of corporate governance for the stability and equity of society is captured in the broader definition of the concept offered by Cadbury for the World Bank (2000): 
"Corporate governance is concerned with holding the balance between economic and social goals and between individual and communal goals. The governance framework is there to encourage the efficient use of resources and equally to require accountability for the stewardship of those resources. The aim is to align as nearly as possible the interests of individuals, corporations and society."

Indeed the OECD proposed a broader and more responsible definition and purpose of corporate governance when it first published the OECD Principles of Corporate Governance: "A good corporate governance regime helps to assure that corporations use their capital efficiently. Good corporate governance helps, too, to ensure that corporations take into account the interests of a wide range of constituencies, as well as of the communities in which they operate, and that their boards are accountable to the company and to the shareholders. This, in turn, helps to assure that corporations operate for the benefit of society as a whole. It helps to maintain the confidence of investors - both foreign and domestic - and to attract more 'patient' long term capital" (OECD 1999: 7).

Business corporations have a considerable and enduring impact upon societies and economies, and how corporations are governed - their ownership and control, the objectives they pursue, the rights they respect, the responsibilities they recognize, and how they distribute the value they create - has become a matter of the greatest significance, not simply for their directors and shareholders, but for the wider communities they serve. Historically different approaches to financing corporations and the resulting corporate governance in different regions of the world have prevailed since the diverse origins of capitalism. The corporate form evolved from family and closely held ownership, through managerial capitalism in the early $20^{\text {th }}$ century and limited liability, and finally to more dispersed forms 
of ownership with protection of minority interests. With different routes, different destinations were reached in corporate governance, company law and institutional development in Anglo-American, European and Asian forms of corporate enterprise (Hall and Soskice 2001; Clarke and dela Rama 2006). While the Anglo-American approach to corporate governance is firmly associated with market-based institutions, in Europe more managerial forms of governance have continued, and in Asia strong elements of family ownership have survived intact.

This has resulted in two parallel universes of corporate governance (Coffee 2000): firstly a dispersed ownership model characterised by liquid securities markets, disclosure, and transparency, where the market for corporate control is the ultimate disciplining mechanism. Secondly a concentrated ownership model characterised by controlling shareholders, weaker securities markets, and less disclosure and transparency, and often with a monitoring role for banks with a stake in the company. The dichotomous ownership models are described by a variety of names including market systems and block-holder systems, rules based and relationship based systems, and market based and bank based systems, but the simplest characterisation is between outsider and insider based systems.

Outsider market based systems are typified by dispersed ownership, a clearer separation of ownership and control, lower debt to equity ratios, and more sophisticated financial markets. In this system there is apparently less incentive for outsiders to attempt to participate in the control of the corporation, except through equity markets. The interests of outside investors are not formally represented in the governance of the corporations, and investors often have less interest in the strategic goals of the enterprise than in short term returns. In contrast insider, relationship based systems are typified by highly concentrated ownership which is 
closely connected to managerial control of the enterprise, with high debt to equity ratios, and with a higher rate of bank debt due to the close relationship with banks who are often represented on the boards of major corporations with other stakeholders including related firms. In these systems hostile takeovers rarely occur, and there is a dense network of supportive relationships with related businesses that can lead to collusion. As Aguilera and Jackson (2010) conclude these models or frameworks of corporate governance remain useful, but need to be refined to fit the empirical realities of different countries.

Claessens and Yurtoglu (2012:3) offer a useful distinction between two aspects of corporate governance: "The first set of definitions concerns itself with a set of behavioural patterns: that is, the actual behaviour of corporations, in terms of such measures as performance, efficiency, growth, financial structure, and treatment of shareholders and other stakeholders. The second set concerns itself with the normative framework: that is, the rules under which firms are operating — with the rules coming from such sources as the legal system, the judicial system, financial markets, and factor (labour) markets." At its most legal and formal, corporate governance focuses on the rules of capital markets governing equity investments in listed companies, including listing requirements, insider dealing, disclosure and accounting, and the protection of minority shareholder rights. In an authoritative statement of the mainstream view, the benefits of robust corporate governance have been concisely summarised by Claessens and Yurtoglu as:

- Increased access to external financing by firms can lead, in turn, to larger investment, higher growth, and greater employment creation.

- Lowering of the cost of capital and associated higher firm valuation makes more investments attractive to investors, also leading to growth and more employment. 
- Better operational performance through better allocation of resources and better management creates wealth more generally.

- Reduced risk of financial crises, which is particularly important given that financial crises can have large economic and social costs.

- Better relationships with all stakeholders, which helps improve social and labor relationships, and help address such issues as environmental protection, and can help further reduce poverty and inequality (2012:12).

To an important degree, all of these claims regarding the potential benefits of corporate governance have substance, and the economies that have worked to develop the robustness of their corporate regulation and corporate governance have generally been among the most successful, the corollary also being true that economies that have marginalised and neglected corporate regulation and institutions, or abandoned these to systemic corruption, have indeed suffered the consequences of stalled economic growth with the increased cost of capital and difficulty in securing equity investors (Laeven 2001; Bekaert and Harvey 2002; Klapper and Love 2002). However each of the points made by Claessens and Yurtoglu carry further implications that require careful negotiation to ensure that strengthening regulation and corporate governance does not have damaging unintended consequences. For example increased access to external financing carries risks that financial interests come to dominate corporate purpose and strategies as Anglo-American corporations have experienced under the servitude of shareholder value, where, as Shleifer and Vishny confidently assert "Corporate governance deals with the ways in which suppliers of finance to corporations assure themselves of getting a return on their investment' (1997: 737). 
The enhanced influence of external investors, redefining operational performance and reallocating resources may well generate greater profitability, but this resulting wealth may be distributed very unequally, as in Lazonick's (2014) critique of profits without prosperity in the current increasing inequality exhibited in the United States. Finally some approaches to corporate regulation and corporate governance do focus upon developing better relationships with all stakeholders, and recognising a wider sense of social and environmental responsibility, but the insistent assertion of shareholder primacy that has typified the AngloAmerican approach to corporate governance in recent decades has undermined the effort to maintain a recognition of the broader responsibilities of corporations (Clarke 2015).

The corporate governance institutions and practices in emerging markets traditionally were, and often remain, markedly different to the preconceptions that inform the dominant international standards. The separation of ownership and control heralded by Berle and Means (1932), and transformed by agency theorists into the key problem of a conflict of interest between diffuse outside shareholders and managers with small amounts of equity in the firm (Jensen and Meckling 1976). Yet international survey research finds that the separation of ownership and control is the exception worldwide, and particularly in emerging markets (Aquilera et al 2012; Claessens, Djankov and Lang 2000). In reality the hegemonic market based conception of corporate governance with managers acting as agents for dispersed shareholders is present (and only to a degree) in the Anglo-American economies, and throughout the rest of the world encompassing Europe, Asia, South America and Africa, more relationship based modes of governance are widely practiced. 
The concentration of ownership common throughout emerging economies has profound implications. La Porta, Lopez-de-Silanes, and Shleifer (1999) surveyed 27 countries and conclude that "the principal agency problem in large corporations around the world is that of restricting expropriation of minority shareholders by the controlling shareholders." Claessens, Djankov, Fan and Lang (1999) identify the ownership \structure of firms in nine East Asian countries and conclude that the main corporate governance problem in these countries is the expropriation of minority shareholders by controlling shareholders. Lins (2000) relates ownership structure to firm value across 22 emerging markets. This research traces through pyramidal shareholding structures to identify a firm's ultimate owners (Gibson 1999). La Porta, Lopes-de-Silanes, Shleifer and Vishny (1998) demonstrate that in countries where the legal system does not do a good job of protecting shareholders' rights, concentrated ownership is more prevalent. If legal, regulatory and market institutions are relatively undeveloped this will have further consequences. In advanced economies, companies are disciplined by a combination of internal and external controls. Internally the company directors' duty is to ensure adequate financial controls are exercised, and this is reinforced by independent audit of the annual accounts. Externally there is a legal framework of corporate law, policed by regulatory authorities. Finally there is the capital market which exercises a commercial discipline upon companies. While these institutional structures might have been in place in the emerging economies in the past, often they did not work properly, as Prowse (1998) concludes:

"In a less evolved regulatory, legal and institutional environment, information asymmetries are more severe, contracting costs are higher because standard practices have not been developed, enforcement of contracts is more problematic because of weak courts, market participants and regulators are less experienced, and the economy itself is likely to be undergoing more rapid change than in developed countries. In such circumstances it is not 
surprising that the competitive environment is weaker and markets do not work as well as in developed countries. In addition to having a weak judicial system, developing countries are unlikely to have administrative agencies that can handle issues that benefit from detailed rule making and non-legal administrative enforcement, such as accounting standards, financial disclosures and stock market listing rules."

Where the institutional and regulatory processes do not work properly, there is even greater reliance on firm-level corporate governance in emerging economies to reassure investors (Francis et al 2003). As Bell et al (2014) state "Our research to date reveals that emerging market companies have to make an even greater effort to adhere to the highest level of corporate governance standards - in some cases well beyond what their home country requires - if they are to succeed in the global marketplace. To achieve the same level of valuation in the US as a similar US-based company, for example, firms from emerging markets need to have a lot more governance than the US company. For these companies, good governance serves as a proxy of sorts for being well-run, healthy and effective. The extent of their global success will depend not just on production efficiencies and other typical business benchmarks, but on how well they can adapt to the multinational policy and regulatory pressures in their various target markets."

In the survey of corporate governance practices in emerging markets by the international organisation of securities regulators (IOSCO 2007:5) evidence suggested that in all the responding jurisdictions the basic rights of shareholders are addressed including rights to:

a. a secure method of ownership registration

b. the transfer of shares

c. capacity to obtain timely relevant information on the company 
d. right to participate and vote in general shareholders meetings

e. right to elect members of the board

f. right to a share in the profits of the company, and

g. right to participate in and be informed on decisions concerning fundamental corporate changes.

According to IOSCO: "Almost all of the responding jurisdictions have provisions in their laws/rules/regulations/listing agreements for prohibition of insider trading." Yet IOSCO goes on to acknowledge that "Prescription of corporate governance principles being still an emerging area, instances of corporate governance related violation are recorded and acted upon in few of the responding jurisdictions. However, most of the jurisdictions are gearing up to address the issue of identification and enforcement of prescribed corporate governance rules in their respective jurisdictions."

The question is - will the continuing weaknesses of these governance and legal institutions in the emerging market economies put any limit upon further international growth, and make more vulnerable the existing gains of the high growth emerging economies? Earlier economic crises in the emerging market economies induced by inadequate financial, regulatory and governance institutions have often proved very sharp, but short-lived as in the Asian financial crisis, where an export-led recovery fuelled renewed growth, followed by a further effort at reform and institution building (Clarke 1999; 2002; Haley and Richter 2002).

\section{Table 1}

\section{Growth of Emerging Economies}




\section{The Sustained Economic Growth of the Emerging Market Economies}

Though corporate governance and regulatory institutions remain in a developmental stage in most of the emerging market economies, this in itself has not impeded significant and sustained economic growth. In the large BRICS economies, China and India have continued with impressive growth rates despite uncertainty in the global economy, South Africa and Brazil have slowed, and Russia has meandered along its own unpredictable geo-political path (IMF 2014). The overall advance of the major emerging market economies including the BRICs despite governance institutions at various stages of development, suggests there are other strengths to these economies that promote dynamic entrepreneurship. Indeed the pattern of growth in the emerging economies compared to the advanced economies from 2000 to 2014 suggests the era of the advanced economy domination of the global economy may be drawing to a close, and could be replaced by a multi-polar world economy in the coming decades (Table 1). It is quite unlikely that the economic hegemony the advanced economies enjoyed in the period from the 1960s through to the end of the 1990s will return.

It is not just the emerging market economies that have experienced burgeoning growth, they have been joined by the low income countries (LICs) that have made a comeback in the last two decades, more LIC economies have experienced take-offs, and these have lasted longer in duration than earlier episodes of take-off. Growth in the LIC's output per capita rebounded beginning in the 1990s. Furthermore, they have grown at a faster pace than advanced economies since the turn of the 21 st century and have even outpaced other emerging market and developing economies (Figure 1). The IMF (2013:97) asks if this could be the beginning of a new era for LIC growth and convergence? In the 1960s and 1970s similar promising 
growth was followed by economic deceleration in the more difficult global economy of the 1980s, inducing pessimism the low income countries could never escape poverty and economic divergence given their weak institutions, slow economic reform, and resourcecurse issues. However there are grounds for some optimism regarding the current LIC's economic growth compared to earlier periods since it has been achieved without strong macro-economic imbalances, with greater foreign direct investment, and less public and external debt accumulation. Further the post 1990s LIC's growth is associated with more robust structural reforms and institution building, with more investment in infrastructure and higher education (IMG 2013:119.)

\section{Figure 1}

\section{Economic Performance of Low Income Countries, Emerging Market and Developing Economies, and Advanced Economies 1960-2011}

Again it must be questioned whether this optimism concerning the future growth of the emerging markets and low income countries can survive a fundamental shift in the global economy. The impact of the US Federal Reserve's withdrawal from quantitative easing will be test profoundly the resilience of the emerging markets:

"For six years, emerging markets have lived in a world defined by the United States

Federal Reserve's policies of easy money. Tides of liquidity have flowed from developed to developing economies, financing infrastructure and corporate investment and allowing consumers to indulge credit-fuelled dreams. Thus the Fed's announcement that it would draw quantitative easing to an end represents both a 
watershed and a leap into the unknown. The end of asset purchases comes at a challenging time for emerging markets best defined by a confluence of adverse and inter-connected trends" (Financial Times, 31 October 2014).

Not only is there the end of the commodity boom, with the sliding prices of commodities for the emerging markets to contend with. The debt markets of the emerging markets have been fuelled with quantitative easing funds that have financed government deficits, infrastructure projects, and company investments. For example foreign ownership in local emerging market bonds has risen from 8 per cent in 2007 to 17 per cent in 2012 according to the Bank for International Settlements, while the size of domestic securities markets in the emerging markets increased by a third to over US 16 trillion (Turner 2014). Yet there are reasons why the strength of the economies of the emerging markets will not dissipate in future periods of economic uncertainty occasioned by economic changes in the advanced industrial economies. The emerging economies are now stronger local economies increasingly trading among themselves, and therefore will remain attractive to overseas investment (PWC 2012: Accenture 2012). The economic resilience of the emerging economies is growing, as Kose and Prasad (2010) state, "Emerging Market Economies (EMEs) have become prominent on the world economic stage, accounting for a substantial fraction of global growth and rising in importance by virtually any economic criterion. In particular, EMEs now play an increasingly important role in international trade and financial flows, implying major shifts in the patterns of global linkages. These developments are likely to have wide-ranging implications for the structure of the global economy." 


\section{The Business and Governance Models of the BRICS Economies}

In assessing the developing business models and corporate governance of the emerging market economies, the leading BRICS economies are a good indicator of the regional pattern. Each of the BRICS represents important emerging market regions: Brazil is at the forefront of a new resurgence in the South American economies; Russia is to an extent indicative of the continuing travails of the East European and central Asian emerging economies (at least those that were once part of the USSR); the two super economies of India and China are the major players in the rapid advance of the Asian economies; and finally South Africa leads the way for a revived set of African economies. Where the BRICS lead it is likely that other emerging economies in their regions will follow, and it is therefore useful to examine some of the unique elements of the economies, institutions and governance of the BRICS markets.

\section{BRAZIL}

Brazil is one of the most vibrant of the emerging economies and, with China and India, is one of the major international forces for changing the political economy of the world. In 2012 Brazil became the sixth largest economic power (displacing the UK) with a nominal GDP of two trillion dollars. Brazil has experienced considerable increases in FDI at the same time as its own multinationals have made unprecedented investments overseas. Brazil has 223 of the largest 500 companies in Latin America, many of which are becoming multilatinas, extending their influence across the continent and globally (Santiso 2013:43). Brazil has succeeded with a range of national champions including Petrobas, one of the world's largest oil corporations. With a government insistence that $65 \%$ of Petrobas supplies must be sourced 
locally the company has diversified and is supporting high technology clusters. The finance sector has remained robust in Brazil throughout the global financial crisis, and has diversified while retaining some banks in public ownership. In aerospace the Brazilian Embraer has come to rival Bombardier and Dassault. Brasil Foods, JBS Friboi and Marfrig are agribusinesses successful internationally. Finally Ambev the largest brewing company in Latin America merged with the Belgian company Interbrew and together they acquired AnheuserBusch in the US. This combination of ambition and pragmatism, together with the state and the private sector working closely together has defined the Brazilian economy.

Corporate governance in Brazil remains a work in progress. The long-standing critique of corporate governance in Brazil and throughout much of South America is that there is a high concentration of business and family group ownership, with a close network of crossownership by industrial firms, and with banks as major shareholders. This leaves little place for minority shareholders, and this was reflected in small and often nominal boards of directors with few independent directors. While most significant elements of corporate law have long been enacted under the civil law, there has in the past been little attempt to implement this in practice. This traditional approach to corporate governance is typical in the region as Reyes (2007) states "The emphasis on corporate governance principles in Latin America should be placed not only on directors' duties, but also on the effective protection of minority shareholders and other stakeholders against the undue appropriation of corporate assets by block-holders. Above all, a determining factor for poor corporate governance in this region relates to the prevailing weakness of the legal infrastructure and, specifically, the comparative lack of enforceability." However in recent years serious efforts have been made at reform of the Brazilian corporate governance system in line with its new standing as an emerging global economic power. The Brazilian stock exchange created the Novo Mercado 
in 2000 offering higher standards of corporate governance for companies willing to be listed. Changes in the Brazilian Securities and Exchange Commission listing rules have raised disclosure standards including director and officer compensation, and made it easier for them to attend company meetings. With the growth of institutional shareholders, shareholding has become more diffuse, and boards of directors more informed of their duties to take decisions in the best interests of the company (OECD 2007b; Bedicks 2012).

\section{RUSSIA}

Russia enjoyed almost a decade of resource-fuelled significant economic growth in the 2000s, but this has now stalled and geopolitical risks, policy uncertainty and sanctions resulting from the Ukraine separatist incidents have reduced the economy almost to stagnation. While having the richest resources of the BRICS economies, and having demonstrated that it is capable of exploiting them in pursuit of economic growth and infrastructural investment, Russia continues to struggle with processes of legal reform and corporate governance accountability and transparency. This institutional weakness will need to be resolved if Russia is to remain as dynamic as the other BRICS economies. There are under way significant reform initiatives, but how they will fare when confronted by entrenched industrial and political oligarchies remains an open question.

A "Russian discount" has negatively affected all Russian corporate issuers, spurring many to seek dual or even sole listings on overseas stock exchanges. A large group of 32 international institutional investors representing eight countries with over $\$ 4.9$ trillion under management representing equities, corporate debt and sovereign debt with actual or potential 
exposure to the Russian securities markets commented to the OECD-Russian Corporate Governance Roundtable regarding the proposed revisions to the Russian Federation's Code of Corporate Governance: “Russia’s scores in the World Bank Public Governance Indexes on indicators such as Rule of Law, Regulatory Quality and Corruption have plateaued over the last decade, and lag behind fellow BRICs and substantially behind the OECD average. Equally, we note that the World Bank's Doing Business rating of Russia stands at 112th out of 185 in 2013. We therefore welcome President Putin's goal of improving the country's ranking to 20th by 2018 and emphasise the comfort that the World Bank Public Governance Indexes provides" (OECD 2013b). The investors noted that despite Russia's highly attractive fundamentals, investment exposure is affected by "significant concerns about the high level of risk associated with standards of corporate governance, ownership structures, investor protections and the overall judicial and regulatory climate.” In 2012 average P/E ratios of Russian companies reflected these risks, with Russia at 5.3x, while India managed 16.1x, Brazil 12.8x, and China 10.0x.

In a broad effort at reform of corporate regulation and governance in Russia the Moscow Exchange established a new premium market segment Novy Rynok, aimed at encouraging higher standards of corporate governance and resulting higher valuations. However Russian law lacks an effective definition of the fiduciary obligation for board directors comprising a duty of care and duty of loyalty in the context of broader concerns regarding the enforceability of contractual agreements, related party transactions, and consistent levels of disclosure, and oversight of executive pay. The Russian economy continues to possess innate strengths and huge potential, but Russian investors prefer to keep their money in the bank, and overseas investors are yet to be convinced of the security of the Russian investment markets. 


\section{INDIA}

As China did before, India is now engaged in a dynamic escape from mass poverty through economic growth, with the population experiencing extreme poverty reducing from 37 per cent in 2005 to 22 per cent or 270 million people in 2012. However 56 per cent of India's population still lack the means to meet essential needs or access to essential services including adequate education, health care and sanitation. (McKinsey Global Institute 2014:2). India's considerable business success has been largely confined to a few states and regions, and a limited number of large companies in specific sectors, while the great majority of the population remain employed in very small, unproductive enterprises. If India can tackle the problems of job creation in growing manufacturing and construction sectors, lift farm productivity, and provide better basic public services there would be the foundations of a continuing economic miracle. Improved political and corporate governance will be central to this task, providing stricter accountability, transparency, effective performance, anticorruption frameworks and simplifying the legal and regulatory system (McKinsey Global Institute 2014:25). India's highly centralised, heavily regulated economy is undergoing change in an entrepreneurial direction, led by the IT services sector.

Infosys, Tata Consultancy Services (TCS), and Wipro are three international IT services giants leading an industry that is the growth engine of the Indian economy. These firms followed processes of upgrading through several business models, commencing with simple technical services such as coding, then becoming prime subcontractors for overseas based multinational corporations, finally offering a full service global delivery model covering all elements of the information technology services value chain. This capacity to transform Indian businesses into large multinational corporations has been experienced in the oil and gas industries; Reliance Industries in energy and petrochemicals products, with Tata motors 
the world's fifth largest truck manufacturer, Tata Steel, aluminium rolling, Bharti Airtel telecommunications, and Larsen and Toubro engineering and construction company.

In the past India has had a weak system of corporate governance. In the absence of a welldeveloped stock market, state financial institutions offered soft loans which consolidated owners and management's position regardless of performance, as when companies defaulted on loans years passed before the resolution of liquidation occurred in proceedings. The inadequacy of these insolvency procedures allowed management to act irresponsibly and undertake risky investments without the fear of insolvency and liquidation when creditors took action. Reviewing the dire state of Indian corporate governance (Chakrabarti 2005) concluded there was hope for the prolonged reform effort:

"With the legacy of the English legal system, India has one of the best corporate governance laws but poor implementation together with socialistic policies of the prereform era has affected corporate governance. Concentrated ownership of shares, pyramiding and tunnelling of funds among group companies mark the Indian corporate landscape. Boards of directors have frequently been silent spectators with the DFI nominee directors unable or unwilling to carry out their monitoring functions. Since liberalization, however, serious efforts have been directed at overhauling the system with the SEBI instituting the Clause 49 of the Listing Agreements dealing with corporate governance. Corporate governance of Indian banks is also undergoing a process of change with a move towards more market-based governance."

\section{CHINA}

When China commenced its open door and reform polices in 1978, its per capita income was less than 10 per cent of the world average in PPP-adjusted dollars, and through relentless dynamism according to World Bank development indicators, by 2012 China's per capita 
income had reached half of the world average, allowing hundreds of millions of Chinese people to escape absolute poverty (Lee 2013:189). The East Asian Tiger economies had maintained growth rates above $7 \%$ for two decades in the 1970s and 1980s, and with a vastly greater population than all of the East Asian economies combined, China sustained double digit growth rates for longer, which continued into the 2000s (Clarke 1998). At the turn of the millennium China's growth expanded meteorically: "In the twenty years from 1978-1998, Chinese GDP increased by $\$ 871$ billion, whereas in the 14 years thereafter (1999-2013) GDP increased by an incredible $\$ 7,339$ billion" (Roland Berger 2014:15). The IMF has projected that by the end of 2014 China will make up $16.48 \%$ of the world's purchasing-power adjusted GDP (or \$US17.632 trillion), and the US will make up just 16.28\% (or \$US17.416 trillion), though in terms of market value China still lags the US in 2013 by US $\$ 6.5$ trillion (IMF 2014).

Not only does China have the three largest banks in the world by assets, but also leading oil corporations; Lenovo who acquired IBMs computer business; Haier the world's largest refrigerator maker; Huawei which is becoming the leading telecoms corporation in the world; and other innovative businesses that are now competing against the multinationals. China has pursued a unique strategy of acquiring technological capabilities and accessing overseas knowledge: forward engineering with university spin-off firms (compared to the reverse engineering of Korea and Taiwan); acquiring international brands through international mergers and acquisitions; and parallel learning from FDI firms to promote indigenous Chinese companies (Lee 2013: 192; Lee et al 2011).

China has a diversified economy with large Chinese multinationals, overseas multinationals, large state enterprises, and town and village enterprises that were often significant players, together with a rump of small private enterprises, all with distinctive modes of governance (Clarke 1998). As the market sector and equity markets have grown rapidly, corporate 
governance has attracted more interest. From meagre beginnings the China A-share market has expanded massively over the last two decades. The Shanghai and Shenzhen stock exchanges now have more than 2,500 stocks with a total market capitalization of about US \$3.9 trillion. Yet despite the establishment of China's Qualified Foreign Institutional Investor (QFII) scheme a decade ago foreign participation accounted only for one per cent of the market capitalization at the end of 2011. This low proportion of foreign ownership is due to the stringent requirements of the QFII system and the slow deployment of the QFII quota, but as these barriers are lowered global investors will arrive (MSCI 2014). A more critical view of the marketization of China is offered by Liu (2006) who cites Wu Jinglian: “'China's stock market is worse than a casino. At least in a casino there are rules.' The China Securities Regulatory Commission (CSRC), records more than 70 million investment accounts have been opened across China: "Roughly 200-300 million Chinese people, directly or indirectly, invest in the stock market. A large amount of bank lending has also been shifted into the stock market by interest groups through various channels (most of them are grey or illegal), even though the precise number is difficult to ascertain. An inefficient, resource-draining stock market is a drag on the Chinese economy and may hamper its ability to maintain the 78 percent growth required to keep unemployment in check" (Liu 2006).

However despite the froth of China's stock exchanges it is often private businesses that are thriving. Qian and Qian (2005) suggest that China's experience is an important qualification of the law, institutions, finance and growth literature: "Neither its legal nor financial system is well developed, yet it has one of the fastest growing economies. While the law-financegrowth nexus applies to the state sector and the listed sector, with arguably poorer applicable legal and financial mechanisms, the private sector grows much faster than the others and provides most of the economy's growth. The imbalance among the three sectors suggests that 
alternative financing channels and governance mechanisms, such as those based on reputation and relationships, support the growth of the private sector."

\section{SOUTH AFRICA}

After some decades of halting growth Africa has sustained a 4.9 per cent compound rate of economic growth between 2000 and 2013, double the rate of growth between 1980-2000. Africa is now second only to East Asia in economic growth, and is home to 8 of the world's fastest growing economies, and the African continent's GDP is now larger than India's, attracting \$545 billion private capital flows from 2003 to 2012, with \$1.6 trillion of flows in goods, services and finance in 2012 up from $\$ 400$ billion in 2000 (McKinsey \& Co 2014). Demographically Africa appears to be travelling in the opposite direction to the rest of the world with an increasingly youthful population, and is set to have the largest working age population of any continent by 2035 (McKinsey 2014). South Africa remains the model for much of the rest of Africa with its relatively stable economy, and progressive institutions. South Africa has strengths in agriculture, mining and manufacturing with internationally successful minerals exports, vehicle manufacturing, food processing, clothing, telecommunications, energy, financial and business services. South Africa has a dynamic business environment with 17 of Africa's leading companies based there including Sasol (chemicals), MTN Group (telecoms), Bidvest (diversified), Eskom (electricity), and Shoprite (retail). Yet there is widespread poverty still co-existing with affluence in South Africa, and 25 per cent of the population are unemployed.

South Africa has maintained a sophisticated legal, regulatory and corporate governance system, with a well-developed stock market representing $278 \%$ of GDP. It compares well with both Europe and the United States in the application of international codes of corporate 
governance policy and practice. South Africa has gone beyond standard corporate governance approaches, and introduced the concept of sustainability and corporate environmental and social responsibility into its corporate governance code, and is one of the first economies to consider integrated reporting on these aspects of business performance with financial reporting. This is a pioneering effort to link shareholders and stakeholders interests.

\section{Table 2}

\section{Different Approaches to Corporate Governance in BRICS Emerging Markets}

This brief survey of the major BRICS economies demonstrates the considerable differentiation that exists between them, but even more so, with the exception of South Africa, the BRIC economies stand in stark contrast to the Anglo-American model of developed legal and regulatory structures, and market oriented corporate governance.

\section{Capital Market Pressures for Convergence in Corporate Governance}

Intense debate over the last decade has concerned the relative merits of the different corporate governance systems, often with the assumption that the Anglo-American system with stronger security markets and higher levels of disclosure represents a more advanced and efficient mode of corporate finance and governance, and leading to the conclusion that inevitably there will be either an early, or more gradual, shift of the European and Asian systems of corporate governance towards the Anglo-American model (Hansmann and Kraakerman 2001; McCahery et al 2002; Hamilton and Quinlan 2005). However the argument for inevitable convergence has tended to underestimate the extent of the different orientations and objectives of the alternative systems; the different institutional complementarities that have evolved; and has failed to appreciate the significance of different 
cultures and conceptions of what a company is (Branson 2001; McDonnell 2002; Gordon and Roe 2004). In different regions of the world there are deeply embedded differences regarding business values and ways of doing things, and very different relationships with stakeholders. There exist profoundly contrasting beliefs in the role of the market in the different systems, which influence the way the corporation is considered: simply as a bundle of tradable assets in the worst case scenario of the market based system; but as a productive institution to be passed on to future generations in the best case of the insider governance system. As a result different measures of performance are applied, with the market based system looking for short term returns, and the European and Japanese systems having much longer term horizons (Clarke and dela Rama 2006: xxi).

As Joseph Stiglitz the former chief economist at the World Bank has insisted, assumptions regarding the inherent superiority of Anglo-American governance institutions have been shaken:

"What makes for good institutions? And how can we create them? During the East Asian crisis, there was much discussion of the weaknesses of the East Asian institutions - financial institutions, financial regulatory bodies, corporate governance. Many were told to imitate U.S. institutions. Since then, confidence in what makes for good institutions has weakened. The Enron and WorldCom scandals highlighted weaknesses in accounting, financial institutions, and corporate governance in the United States. But the subsequent passage of the Sarbanes-Oxley Act gave renewed confidence in the institutions of the United States: its public institutions had faced up to the underlying weaknesses in corporate governance and had taken action. I was more sceptical. I had argued that perhaps the most fundamental flaw had to do with stock options, which provided incentives for bad accounting and short-sighted behavior (Stiglitz 2003b). But nothing was done. I and others had worried too about 
the bonus system that had encouraged excessive risk taking and the lack of regulation. I had worried that securitization was increasing problems of information asymmetries and decreasing the quality of lending (Stiglitz 2003a). Few would say today that the institutions of the U.S. financial sector-its rating agencies, its regulatory authorities, or its commercial or investment banks — are exemplary" (World Bank 2009:147).

The era of unquestioned Anglo-American institutional ascendancy may be drawing to a close. As Keaneand Velde (2011) indicate in the the new landscape of global economic governance there will be a gradual strengthening of the role of emerging economies: " The years to 2020 are most likely to be characterised by a continued shift in economic, and therefore political, power from the US and Europe to China, Brazil, India and several other large developing countries...Developments in the governance roles being played by the new emerging powers within global economic decision making bodies such as the G20, IMF, World Bank, WTO, and UNFCCC. As has been shown, the key issues and current sticking points within each of these institutions can be seen to be boiling down to stand-offs between the declining hegemonic power - the US - with the new emerging powers" (2011:35-37)

\title{
Cultural and Institutional Tendency Towards Diversity
}

\author{
"There is no single model of good corporate governance" \\ OECD (2004) Principles of Corporate Governance, p13
}

The OECD Principles of Corporate Governance are one of the 12 key standards for the international financial stability of the Financial Stability Board (FSB) and form the basis for the corporate governance component of the Report on the Observance of Standards and Codes of the World Bank Group. The OECD (2004)Principles are currently under review 
"which embrace the shared understanding that a high level of transparency, accountability, board oversight, and respect for the rights of shareholders and role of key stakeholders is part of the foundation of a well-functioning corporate governance system. These core values should be maintained and, as appropriate, be strengthened to reflect experiences since 2004."

But though these essential principles might be found in many different corporate governance systems, the degree of toleration of institutional diversity of the OECD remains to be seen. In the OECD's (2007) Methodology of Assessment of Principles of Corporate Governance there is an emphasis on functional equivalence: that is there are many ways of achieving similar outcomes, therefore recognising that implementation of the Principles needs to be adapted to national circumstances.

James D. Wolfensohn the President of the World Bank had a more expansive view about institution building as expressed in the World Development Report 2002, "Design them to complement what exists - in terms of other supporting institutions, human capabilities, and available technologies. The availability and costs of supporting institutions and capacity determine the impact of any particular institution. By understanding how institutions interact, we can identify priorities. Innovate to identify institutions that work..” (2002, p iv)

As Aguilera and Jackson (2010) state when corporate governance practices, especially those tied to a shareholder value ideology are exported from the United States to other countries "they tend to be translated and recombined with the local practices before they are adopted. As a result, only certain dimensions of the governance practice are fully implemented and their adaptation often leads to new or hybrid forms of these practices" (2010: 487). The Asian Productivity Organisation expresses the bewilderment often caused by the unthinking imposition of corporate governance regimes which make little local sense: "Corporate 
governance is not only a method firms use to discipline themselves while remaining profitable. It is also one of the principal ways they "make the society" in which they operate and which in turn "makes" them. If this relationship is obscured, it is because the existing policy and regulatory environment confronts firms with an apparently ready-made and opaque organization of means and ends, in which compliance is necessary but over whose purpose the majority of organizations, whether companies or civil society groups, have little or no control."

Aras and Crowther (2008) insist "cultural, historical, and institutional factors and contexts are critical influential factors to consider in developing better and more effective governance practice." Corporate governance has to blend with deeper institutions and values, as Kar suggests in an Indian context, "corporate governance includes moral values, ethics, and concepts that are largely defined by the cultural and personal contexts in which they exist. Concepts of equity, fairness, and stewardship have deep moorings" (2011).

A consequence of the differences in corporate governance structure and objectives, and the underlying values and cultures in which they are practiced, is that the different systems demonstrate unique strengths and weaknesses: essentially they are good at doing different things, and they all have weaknesses (Moerland 1995; Dore et al. 2002). The AngloAmerican governance system supports a dynamic market orientation, with fluid capital which can quickly chase market opportunities wherever they occur. The downside of this system is the corollary of its strength: the inherent volatility, short termism and inadequate governance procedures that have often left US manufacturing industry stranded, and caused periodic stock market panics and occasional crashes. In marked contrast European enterprise as typified by the German governance system traditionally has committed to a long term 
industrial strategy supported by stable capital investment and robust governance procedures that build enduring relationships with key stakeholders (Cernat 2004; Lane 2003). This was the foundation of the German economic miracle which carried the country forward to becoming the leading exporter in the world of products. Again the weaknesses of the German system were the corollary of its strengths: the depth of relationships leading to a lack of flexibility, that made it difficult to pursue initiatives for new businesses and industries while accumulating costs in established companies.

The Latin variant of European corporate governance as practiced in France and Italy is highly network oriented, with dominant holdings by the state, families, or industrial groups. Ownership concentration provides for stability and long term horizons, with strong relationships with stakeholders. This governance system has allowed the Southern European countries to specialize in selected industries with notable success. However weak governance accountability and frequent network and pyramid control diminishes the integrity of the equity market: the strength of the blockholder relationships precluding others from becoming involved. Finally, the Asian corporate governance system is the most network based of all, with the firm as the institutional centre of long enduring and deep economic relationships of investors, employees, suppliers and customers (Claessens and Fan 2002). In the Japanese system there is a close dependence on bank finance and insider control. This approach has yielded the longest investment horizons of all and was the key to the Japanese success in progressively dominating overseas markets. The Japanese economic miracle came to an abrupt end when paying the price for its own success, the hugely speculative bubble burst in the early 1990s, the resulting decade-long disorientation revealing the weaknesses of secretive and unaccountable Japanese governance. 
What emerges from this analysis is a powerful sense of the viability and vitality of the diversity of corporate governance institutions, as confirmed in the recent survey by Aguilera et al (2012):

"Our findings show that, together with ownership structure, legal systems and their related corporate law, the development and structure of capital, and the political and economic institutions help to constitute the myriad of varieties of capitalisms that characterize corporate governance systems in the emerging economies (Hall and Soskice 2001). And, more importantly, the similarities in ownership concentration level and legal systems only partially account for governance realities in these countries. This implies that to compare corporate governance practices across countries better, we need to take into account their economic history, formal and informal institutions, political processes, social actors, and the choices of firms themselves" (2012:339).

\section{Conclusions}

The narrative of international corporate governance policy and practice in recent decades has proved simplistic and misleading. Principles of honesty, integrity, accountability, transparency and fair dealing are fundamental to the viability and trustworthiness of any corporate system possessing, or actively seeking, external investors. However to assume that 
these principles are bound up with one system of corporate governance, and other systems of governance invariably lack these essential foundations is one-dimensional xenophobia. The assumption that the Anglo-American system alone represents best policy and practice is at best naïve, and at worst part of an ideological thrust to ensure Anglo-American investment interests remain paramount wherever in the world they exist. All systems of corporate governance have serious weaknesses as well as strengths, and this includes the AngloAmerican system which has been at the epicentre of major corporate governance collapses in the $21^{\text {st }}$ century, including the global financial crisis. European and Asia-Pacific governance systems demonstrate strengths and weaknesses too. While economic growth has slowed in Europe, the more inclusive and responsible system of corporate governance practiced there has often maintained more cohesive economies and societies. In the Asia Pacific, and throughout the more dynamic emerging markets, despite ostensibly weaker corporate governance systems, high rates of economic growth have been consistently sustained.

This is not to suggest that corporate governance systems and business growth are unconnected, simply that the apparent weaknesses in corporate governance in the Asia Pacific and elsewhere in the emerging markets have not in themselves held back growth. However it remains clear that prosperous economies require strong institutional foundations in the longer term. If the prosperity of the emerging markets is to be sustained, there will need to be attention to building the viability and strength of their regulatory and governance institutions, which does not mean the unthinking adoption of Anglo-American models. For the economies of the developing world to achieve their true potential and sustain their performance, what is required is for them to improve their own governance system rather than to adopt Anglo-American practices that might lead to hybrid ineffective forms of governance. Governance reform should be designed according to the ethical foundations and 
values of the society in question to remain vital and meaningful, and to contribute to balanced economic development. 


\section{REFERENCES}

Accenture (2012) The Rise of E2E Integration: How Trade and Investment Between Emerging Markets is Reshaping Global Competition, Accenture

Aguilera RV and Jackson G (2010) Comparative and International Corporate Governance. The Academy of Management Annals 4(1): 485-556

Aguilera,R.V., Kabbach de Castro,L.R., Lee,J.H. and You,J. (2012) Corporate Governance in Emerging Markets. In: Morgan G and Whitley R (eds), Capitalisms and Capitalism in the Twenty-First Century, Oxford University Press, Oxford, pp 319-344 http://papers.ssrn.com/sol3/papers.cfm?abstract_id=1806525

Aguilera,R.V., Filatotchev,I., Gospel,H. and Jackson,G. (2008) An Organizational Approach to Comparative Corporate Governance: Costs, Contingencies, and Complementarities, Organization Science, Vol. 19, No. 3, May-June 2008, pp. 475-492

Allen, F., Qian, J. and Qian, M. (2005) Law, Finance and Economic Growth in China, Journal of Financial Economics, 77, 57-116

Asian Productivity Organisation, Best Practices in Asian Corporate Governance, Tokyo http://www.apo-tokyo.org/00e-books/IS-20_BP_AsianCorpGov/IS-

20_BP_AsianCorpGov.pdf

Amann, E. and Cantwell, J. (Editors) (2012) Innovative Firms in Emerging Market Countries, Oxford University Press

Aras,G. and Crowther,D. (2008). Culture and Corporate Governance, in, Güler Aras and David Crowther, Issues in Corporate Behaviour and Sustainability, Social Responsibility Research Network

Bedicks, H. (2012) IBGC: Progress in Corporate Governance - Brazil is also on Board,

Bell, R.G., Filatotchev,I., and Aguilera, R.V. (2014) Corporate Governance and Investors Perceptions of Foreign IPO Value: An Institutional Perspective, Academy of Management Journal, 57, 1, 301-320

Bekaert,G. and Harvey C.R. (2002) Research in Emerging Markets Finance: Looking to the Future, Emerging Markets Review, 3, 429-448

Bouchez L (2007) Principles of Corporate Governance: the OECD Perspective. European Company Law 4(3): 109-115

BRICS Report (2012) Oxford University Press

Cadbury, A. (2000) World Bank, Corporate Governance: A Framework for Implementation (Foreword), Washington: World Bank. 
Caron MI, Ficici A, and Richter CL (2012) The Influence of Corruption on Corporate Governance Standards: Shared Characteristics of Rapidly Developing Economies.

Emerging Markets Journal 2(1): 21-37

Chakrabarti, R., (2005) Corporate Governance in India - Evolution and Challenges, ICFAI Journal of Corporate Governance,

http://papers.ssrn.com/sol3/papers.cfm?abstract_id=649857\&rec $=1 \&$ srcabs $=1012222$

Chen VZ, Li J and Shapiro D M (2011) Are OECD-prescribed 'Good Corporate Governance Practices' Really Good in an Emerging Economy? Asia Pacific Journal of Management 28(1):115-138

Claessens, Stijn, Simeon Djankov, Joseph Fan and Larry Lang, 2002. "Disentangling the Incentive and Entrenchment Effects of Large Shareholdings," Journal of Finance 57, 27412771 .

Claessens, S. and Fan, J. (2002) 'Corporate Governance in Asia,' International Review of Finance, 3, 2, 71-103

Claessens, Stijn, Simeon Djankov, and Larry Lang, 2000. "The Separation of Ownership and Control in East Asian Corporations," Journal of Financial Economics 58, 81-112.

Claessens, Stijn, Simeon Djankov, Joseph P.H. Fan and Larry H.P. Lang (1999), "Expropriation of minority shareholders: Evidence from East Asia," World Bank Policy Research Paper 2088 (March).

Clark, G.L., Feiner, A., and Viehs, M. (2014) From the Stockholder to the Stakeholder: How Sustainability Can Drive Financial Performance, University of Oxford/Arabesque Partners Clarke, T. (2015a) International Corporate Governance, Second Edition, London: Routledge Clarke, T. (2015b) The Long Road to Reformulating the Understanding of Directors' Duties: Legalizing Team Production Theory? Seattle University Law Review, 38, 2

Clarke, T. (2014a) Dangerous Frontiers in Corporate Governance, Journal of Management \& Organization, 20, 3, pp 268-286

Clarke,T. (2014b) The Impact of Financialisation on International Corporate Governance, Law and Financial Markets Review, 8, 1, March, pp 39-51

Clarke.T. (2010a) Recurring Crises in Anglo-American Corporate Governance, Contributions to Political Economy, Oxford University Press, Vol 29, 1, 9-32

Clarke,T. (2010b) Human Capital in Developing Countries: The Significance of the Asian Experience, in J.C.Spender and A.Burton-Jones, The Oxford Handbook of Human Capital, Oxford University Press

Clarke, T. and Chanlat, J-F.(2008) European Corporate Governance, London and New York: Routledge 
Clarke, T., and dela Rama (2006). Corporate Governance and Globalization. London: Sage

Clarke, T. (2005) Corporate Governance: Critical Perspectives, Five Volumes, London:

Routledge.

Clarke, T. (2004a) Theories of Governance: The Philosophical Foundations of Corporate Governance, London: Routledge.

Clarke, T. (2004b) Cycles of Crisis and Regulation: The Enduring Agency and Stewardship Problems of Corporate Governance', Corporate Governance an International Review, Blackwell, 12, 2, April 2004, 152-160

Clarke, T., (2002). Crisis and Reform in Corporate Governance in Asia, in Usha Haley and Frank-Jurgen Richter, Asian Post Crisis Management, London: Macmillan, pp226-251

Clarke, T. (1999) Haemorrhaging Tigers: The Power of International Financial Markets and the Weaknesses of Asian Modes of Corporate Governance, Corporate Governance an International Review, Blackwell, 7, 4, 101-116.

Clarke, T. (1998) Corporate Governance in China: Explosive Growth and New Patterns of Ownership," Long Range Planning - International Journal of Strategic Management, Pergamon, 31(2): 239-251.

Clarke, T. and E. Monkhouse (1995). Repensando a Empresa. São Paulo: Pioneira.

Clarke, T., (1994). Introduction: Privatising the World?, in Clarke, T., International Privatisation: Strategies and Practices, Berlin: Walter de Gruyter, 1994, pp1-22

Davies, G. (2014) A Debate on Emerging Market Turbulence, Financial Time, 16 March 2014

de Búrca, G., Keohane, RO and Sabel, CF (2013), New Modes of Pluralist Global Governance. New York University Public Law and Legal Theory Working Papers. Paper 386. http://lsr.nellco.org/nyu_plltwp/386. Accessed 15 March 2013

Deeg R. and Jackson,G. (2006) Towards a More Dynamic Theory of Capitalist Variety, King's College London, Department of Management Research Papers, Number 40

Demsetz, Harold and Lehn, Kenneth, 1985. "The Structure of Corporate Ownership: Causes and Consequences," Journal of Political Economy 93, 1155-1177

D W Akamemie, Quiet Revolution in Emerging Countries, http://www.dw.de/quietrevolution-of-the-emerging-countries/a-17615162

Euromonitor International (2014) China Overtakes the US as the World's Largest Economy, London: Euromonitor International

European Bank for Reconstruction and Development (EBRD) (2007) Corporate Governance Assessment.

http://www.ebrd.com/pages/sector/legal/corporate/assessment.shtml 
Eurosif (2010) Emerging Markets, $5^{\text {th }}$ Theme Report, Paris: Eurosif

Fazio S (2008) Corporate Governance, Accountability and Emerging Economies. Company Lawyer 29(4):105-113

Fox MB and Heller MA (eds) (2006) Corporate Governance Lessons from Transition Economy Reforms. Princeton University Press, Princeton.

Francis, B,, Hasan, I., Song,L. and Waisman, M, (2013) Corporate governance and Investment-cash Flow Sensitivity: Evidence from Emerging Markets, Emerging Markets Review, 2013, 15, 57-71

Gibson, M.A. (2002) Is Corporate Governance Ineffective in Emerging Markets? Finance and Economics Discussion Series, Divisions of Research and Statistics and Monetary Affairs, Federal Reserve Board, Washington DC

Gilson RJ, Hansmann H and Pargendler M (2011) Regulatory Dualism as a Development Strategy: Corporate Reform in Brazil, the United States, and the EuropeanUnion. Stanford Law Review 63: 475-538

Global Corporate Governance Forum (GCGF) (2013) "Understanding Cultural and Social Forces is Crucial to Improving Corporate Governance". Interview with Bruce Kogut.

http://www.gcgf.org/wps/wcm/connect/topics_ext_content/ifc_external_corporate_site/global +corporate+governance+forum/news/bruce+kogut+interview

Filatotchev, I., Strange,R., Piesse,J. and Lien, Y-C. (2007) FID by Firms from Newly Industrialised Economies in Emerging Markets: Corporate Governance, Entry Mode and Location, Journal of International Business, 38, 556-572

Franks, Julian, Colin Mayer, Paolo Volpin and Hannes Wagner, 2012. "The Life Cycle of Family Ownership: International Evidence,” Review of Financial Studies, forthcoming

Guyot, A. (2011) Efficiency and Dynamics of Islamic Investment: Evidence of Geopolitical Effects on Dow Jones Islamic Market Indexes, Emerging Markets Finance \& Trade, 47, 6, 24-45

Hall, P.A., \& Soskice, D.W. (2001). Varieties of Capitalism: The Institutional Foundations of Comparative Advantage. Oxford: Oxford University Press.

Hollingsworth, J. Rogers and Robert Boyer. 1997. Contemporary Capitalism : the Embeddedness of Institutions, Cambridge, U.K. ; New York: Cambridge University Press.

Hoskisson,R.E., Wright,M., Filatotchev,I. and Peng, M.W. (2013) Emerging Multinationals from Mid-Range Economies: The Influence of Institutions and Factor Markets, Journal of Management Studies, 50, issue 7, pages 1295-1321

ICGN (2014) ICGN Global Governance Principles, International Corporate Governance Network $\quad$ https://www.icgn.org/images/Global_Governance_Principles_2014.pdf 
IOSCO (2007) Corporate Governance Practices in Emerging Markets, Report from the Emerging Markets Committee of the International Organization of Securities Commissions

Iatridis, G.M. (2013) Environmental Disclosure Quality: Evidence on Environmental Performance, Corporate Governance and Value Relevance, Emerging Markets Review, 14, $55-75$

International Monetary Fund (2014) World Economic Outlook: Legacies, Clouds, Uncertainties, Washington: IMF October 2014

International Monetary Fund (2013) World Economic Outlook: Hopes, Realities, Risks, Washington: IMF April 2013

International Organization of Securities Commissions (IOSCO) (2007) Corporate Governance Practices in Emerging Markets. http://www.iosco.org/library/pubdocs/pdf/IOSCOPD261.pdf

Iqbal, Z. and Mirakhor,A. (2013) Economic Development and Islamic Finance, Washington: World Bank

Jackson, G. and Deeg, R. (2006) How Many Varieties of Capitalism? Comparing the Comparative Institutional Analyses of Capitalist Diversity, MPIfG Discussion Paper 06/2, Max Planck Institute for the Study of Societies

Jesover F and Kirkpatrick G (2005) The Revised OECD Principles of Corporate Governance and their Relevance to Non-OECD Countries. Corporate Governance 13(2): $127-136$

Kar P (2011) Culture and Corporate Governance Principles in India: Reconcilable Clashes? Private Sector Opinion, Issue 23, IFC-World Bank, GCGF, Washington, D.C. https://openknowledge.worldbank.org/handle/10986/11070

Keane, J. and te Velde, D.W. (2011) The New Landscape of Global Economic Governance: Strengthening the Role of Emerging Economies, EDC 2020, Seventh Framework Program

Keane, J. and Potts, G. (2008) Achieving Green Growth in a Carbon Constrained World, London: Overseas Development Institute

Kearney, C. (2012) Emerging Markets Research: Trends, Issues and Future Directions, Emerging Markets Review, 13, 159-183

Khan IA (2012) The Role of International Organisations in Promoting Corporate Governance in Developing Countries: A Case Study of Pakistan. International Company and Commercial Law Review 23(7): 223-233

Klapper, L., Love, I., (2002) Corporate Governance, Investor Protection and Performance in Emerging Markets. World Bank 
Kaufman A and Englander E (2006) A Team Production Proposal to the Shareholder Stakeholder Quarrel: The OECD Principles of Corporate Governance. SSRN. http://ssrn.com/abstract=1030846. Accessed 15 March 2013

Kogut B (2012) The Small Worlds of Corporate Governance (Vol. 1), MIT Press, Cambridge, Massachusetts

Kose,A. and Prasad,E. (2010) Resilience of Emerging Market Economies to Economic and Financial Developments in Advanced Economies, European Economy, Economic Papers 411, Directorate General for Economic and Financial Affairs, European Union http://ec.europa.eu/economy_finance/publications/economic_paper/2010/pdf/ecp411_en.pdf

Laeven, L., 2001. Financial Liberalization and Financing Constraints: Evidence from Panel Data on Emerging Economies, Working paper, World Bank

La Porta, Rafael, Florencio Lopez-de-Silanes, and Andrei Shleifer, 1999. "Corporate Ownership around the World," Journal of Finance 54, 471-51

Lazonick, William (2014) Profits Without Prosperity, Harvard Business Review, September Lee, K. (2013) Schumpeterian Analysis of Economic Catch-Up, Cambridge University Press Lee, K., Jee, M. and Eun,J.H. (2011) Assessing China's Catch-Up at the Firm Level and Beyond: Washington Consensus, East Asian Consensus, and the Beijing Model, Industry and Innovation, 18, 5, 487-507

Liu,Q. (2006) Corporate Governance in China: Current Practices, Economic Effects and Institutional Determinants, CESifo Economic Studies Advance, 52,2, 415-453

http://www.econ.hku.hk/ qliu/publication/cgchina.pdf

Masulis, Ronald W., Peter K. Pham and Jason Zein, 2011. "Family Business Groups Around the World: Financing Advantages, Control Motivations, and Organizational Choices," Review of Financial Studies 24, 3556-3600

McKinsey Global Institute (2014) Global Flows in a Digital Age: How Trade, Finance, People and Data Connect the World Economy, McKinsey and Company

McKinsey \& Company (2014) Lions Go Global: Deepening Africa's Ties to the United States, McKinsey and Company

McKinsey Global Institute (2013) Financial Globalization: Retreat of Reset ? McKinsey \& Company

Mitton, T. (2004) Corporate Governance and Dividend Policy in Emerging Markets, Emerging Markets Review, 5, 409-426

Ministry of Finance (2012) The BRICS Report, Government of India, New Delhi: Oxford University Press 
Morck and Steier (2005) Introduction. In: Randall K. Morck RK (ed), A History of Corporate Governance around the World: Family Business Groups to Professional Managers, University of Chicago Press, Chicago, pp 1-64

MSCI (2014) "A" Opening to the Great Wall, MSCI.com

Nielsen L (2011) Classifications of Countries Based on Their Level of Development: How it is Done and How it Could be Done. IMF Working Paper WP/11/31. http://www.imf.org/external/pubs/ft/wp/2011/wp1131.pdf. Accessed 15 March 2013

OECD (2003) White Paper on Corporate Governance in Latin America. http://www.oecd.org/dataoecd/25/2/18976210.pdf

OECD (2006) Corporate Governance in Turkey: A Pilot Study. OECD Publishing. doi: $10.1787 / 9789264028647$-en

OECD (2007a) Methodology for Assessing the Implementation of the OECD Principles of Corporate Governance. http://www.oecd.org/daf/corporateaffairs/corporategovernanceprinciples/37776417.pdf

OECD (2007b) Country Report: Voluntary Corporate Governance Code in Brazil http://www.oecd.org/corporate/ca/corporategovernanceprinciples/39741021.pdf

OECD (2011c) Achieving Effective Boards: A comparative study of corporate governance frameworks and board practices in Argentina, Brazil, Chile, Colombia, Mexico, Panama and Peru. June. http://www.oecd.org/countries/panama/48510039.pdf .

OECD (2012a) Related Party Transactions and Minority Shareholder Rights. OECD Publishing. doi: http://dx.doi.org/10.1787/9789264168008-en

OECD (2013) Supervision and Enforcement in Corporate Governance, OECD, http://www.oecd.org/daf/ca/SupervisionandEnforcementinCorporateGovernance2013.pdf

Peng, M.W., Wang, D.Y.L., Jiang, Y., (2008) An institution-based view of international business strategy: a focus on emerging economies, Journal of International Business Studies 39, 920-936

Preqin (2014) Sovereign Wealth Fund Review, Preqin

PWC (2012) Project Blue: Capitalising on the Rise and Interconnectivity of the Emerging Markets, PWC http://www.pwc.com/gx/en/financial-services/projectblue/rise-of-theemerging-markets-saaame/assets/pwc-project-blue-capitalising-rise-interconnectivityemerging-markets-saaame.pdf

Reyes, F. (2007) Corporate Governance in Latin America: A Functional Analysis, Paul M. Herbert Law Centre, Louisiana State University, SSRN file:///C:/Users/990880/Downloads/SSRN-id1005208.pdf

Roland Berger (2014) East Asian Business, All Parliamentary Group, UK Parliament Santiso, Javier (2013) The Decade of Multilatinas, Cambridge University Press 
Seki,T. and Clarke,T. (2014) The Evolution of Corporate Governance in Japan: The Continuing Relevance of Berle and Means, 37 Seattle University Law Review, 37, pp717-747

Shleifer, Andrei and Robert W. Vishny, 1986. "Large Shareholders and Corporate Control," Journal of Political Economy 94, 461-488.

Shleifer, Andrei, and Robert W. Vishny, 1997. "A Survey of Corporate Governance," Journal of Finance 52, 737-783

Soederberg S (2003) The Promotion of 'Anglo-American' Corporate Governance in the South: Who Benefits from the New International Standard? Third World Quarterly 24(1): 7-27

Stiglitz, J.E. (2009) The World Development Report: Development Theory and Policy, in, Yusuf, S. (2009) Development Economics Through the Decades, Washington: The World Bank, pp 139-153

Turner, P. (2014) The Global Long-Term Interest Rate, Financial Risks and Policy Choices in EMEs, BIS Working Papers no 441, Bank of International Settlements

Villalonga, Belén, 2011. "Does the Value of Family Control Change with Economic Conditions? Working Papers, NYU Stern School of Business

World Bank (2013) Managing Risk and Opportunity, World Bank Development Report 2014, Washington DC: World Bank

World Bank. (2010). Privatisation international database. Washington, DC: World Bank World Bank (2009) Development Economics Through the Decades, Washington: The World Bank

World Bank (2001) Building Institutions for Markets, World Development Report 2002, Washington DC: World Bank

Zhang, X. and Daly,K. (2011) The Determinants of China's Outward Foreign Investment, Emerging Markets Review, 12, 389-398 